\title{
ASSESSMENT OF THE NATURAL-RECREATIONAL RESOURCES OF THE AKMOLA REGION (BASED ON THE EXAMPLE OF THE SHCHUCHINSK-BOROVOYE RESORT AREA) FOR THE PURPOSE OF SUSTAINABLE DEVELOPMENT OF TOURISM
}

\author{
Kamshat YEGEMBERDIYEVA* \\ "Institute of Geography and water security" JSC, 050010 Almaty, Kazakhstan, e-mail: kamshat.yegemberdiyeva@ gmail.com \\ Yuliya YUSHINA \\ "Institute of Geography and water security” JSC, 050010 Almaty, Kazakhstan, e-mail: juliette_glimmer@mail.ru \\ Andrey KHEN \\ "Institute of Geography and water security" JSC, 050010 Almaty, Kazakhstan, e-mail: khenandrey1978@mail.ru \\ Roza TEMIRBAYEVA \\ "Institute of Geography and water security” JSC, 050010 Almaty, Kazakhstan, e-mail: rozatemirbayeva@mail.ru \\ Kuralay ORAZBEKOVA \\ "Institute of Geography and water security" JSC, 050010 Almaty, Kazakhstan, e-mail: kuralay_orazbekova@mail.ru
}

\begin{abstract}
Citation: Yegemberdiyeva K., Yushina Yu., Khen A., Temirbayeva R., Orazbekova K. (2020). ASSESSMENT OF THE NATURALRECREATIONAL RESOURCES OF THE AKMOLA REGION (BASED ON THE EXAMPLE OF THE SHCHUCHINSK-BOROVOYE RESORT AREA) FOR THE PURPOSE OF SUSTAINABLE DEVELOPMENT OF TOURISM. GeoJournal of Tourism and Geosites, 30(2spl), 818-826. https://doi.org/10.30892/gtg.302spl06-510
\end{abstract}

\begin{abstract}
The main purpose of this article is an assessment of the natural-recreational resources of the Akmola region (based on the example of the Shchuchinsk-Borovoye resort area) for their conservation and effective use with a priority for tourism development. The basic natural-recreational resources of the Shchuchinsk-Borovoye resort area are hydrological, botanical and geomorphological resources. The physical-geographical features of the lakes are considered from the point of view of tourist potential (absolute height of the relief, depth and area of the lakes, climate, transport accessibility) in order to assess the hydrological resources. Assessment of the tourist potential of the botanical resource was made on the basis of score-card system according to the degree of suitability for the development of tourism. Also, the results of assessing the tourist potential of geomorphological resources by morphometric indicators are presented in the article.
\end{abstract}

Key words: natural-recreational resource, hydrological resource, botanical resource, geomorphological resource, recreational potential, tourism

* $* * * * *$

\section{INTRODUCTION}

Currently, more and more tourists would like to expand their travel geography, get acquainted with new places, and obtain new impressions. In this situation, Kazakhstan is an object of interest as a country with a large territory, and as a result, having diverse naturalrecreational resources that can satisfy the needs of an experienced tourist.

Each region of Kazakhstan has its own natural features. So, the north of the country, in particular the territory of the Akmola region, is a residual-denudation pediment plain with many plains, diverse flora and fauna, which are of great tourist interest. One of the unique places here is the Shchuchinsk-Borovoye Resort Area (ShchBRA). The feature of the ShchBRA is the complexity of resources (Figure 1). This is a unique granite low-mountain relief, relic coniferous forests, a system of fresh and saline lakes with valuable balneological properties, which in this work are evaluated as the main natural-recreational resources of the region. The ShchBRA is located on the territory of the Burabai State National Nature Park (SNNP "Burabai"), i.e. in a specially protected natural area (SPNA), where any economic activity, including also tourist-recreational one, should be carried out taking into account the need to conserve and restore the ecosystems of the National Park. Any tourism-recreational activities in the ShchBRA should be developed only with priority consideration for environmental restrictions and be based on the results of the assessment of the tourist potential of the territory (Yegemberdiyeva et al., 2018).

\section{MATERIALS AND METHODS}

When assessing the tourist potential of the functional component of a water body, a quantitative (medical-biological and technological) and a qualitative or expert's (sanitary-hygienic, psychological-aesthetic and environmental) assessment is used. Due to the specifics of determining the attractiveness of the zones of water and near-water recreation zones, a complex recreational regionalization is carried out in the territory under study (Litvinov, 2013). According to V.I. Prelovsky (Kuskov et al., 2005), the very concept of "beach-type resources" is considered as the product of the area of the beach, its environmental and psychophysiological load and the duration of the beach season. Assessments of the recreational resources of water bodies can be made according to the basic criteria of the water area for swimming, depending on the degree of favorableness (Ziganshin et al., 2016; Kolotova, 1999). The territory can be assessed in terms of its suitability for certain forms and types in recreational activities in water bodies (Mirsanjari et al., 2008; Buzyakova, 2006). For data visualization, methods of cartographic modeling and GIS technologies are used (Khromeshkin et al., 2015; Mukayev, 2015; Lazitskaya, 2014; Litvinov, 2013; Akhmatov, 2012; Gordeziani et al., 2011; Orlova, 2010; Staroverkina, 2007; Radojević et al., 2007; Shevtsova, 2001; Dorofeyev, 2003).

In the assessment of the tourist potential of the hydrological resources of the ShchBRA, the main emphasis is placed on lakes suitable for organizing and implementing recreational activities, criteria for the favorableness of the recreational properties of water bodies were 
considered on the basis of ranked indicators of natural systems (Rotanova et al., 2011). The evaluation of vegetation of the ShchBRA was carried out by a mixed method with a predominance of desk researches, including the preparatory stage, where cartographic materials were examined, data from official information sites were analyzed, literature of the corresponding profile was reviewed, as well as field studies along the planned routes, on which the boundaries of the contours of plant communities were determined with the description of phytocenoses (Hakim et al., 2017; Sultangazina, 2015).

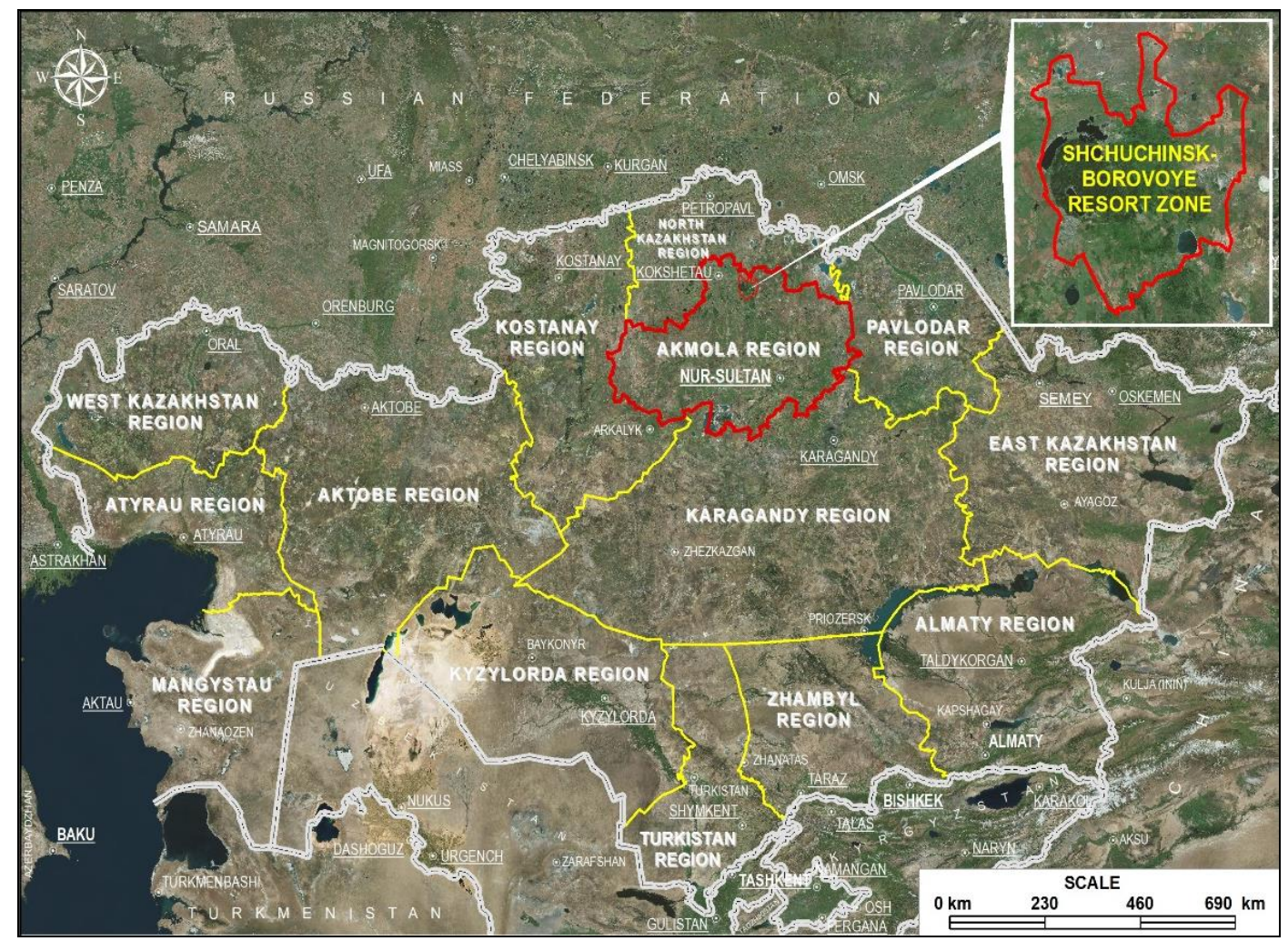

Figure 1. Geographical location of the ShchBRA

The following were considered to assess the vegetation of the territory: natural zonal characteristics of the territories and their species diversity. The boundaries of the contours of plant communities were determined according to the map of vegetation of Northern Kazakhstan (Atlas of Northern Kazakhstan, 1970). Seven basic plant communities were identified on the territory of the ShchBRA. The degree of suitability of vegetation for the development of ecological tourism and recreation was calculated on the basis of score-card system and 4 degrees of favorableness of tourism potential of vegetation of the territory of the ShchBRA were identified. The most favorable are forest and forest-steppe areas, steppes and meadows were evaluated as the middle category, and the territories with halophytic vegetation groups obtained the lowest score. An inventory of the main types of vegetation was carried out in field conditions on the areas of $10 \times 10 \mathrm{~m}$ at different intensities of anthropogenic impact (Dancheva, 2013; Mutaqien et al., 2011).

The morphometric characteristics of the relief determine the internal landscape diversity of the natural system. Despite the fact that the concept of "internal landscape diversity" is related to the landscape, it is the relief that largely determines its morphological structure and forms the general recreational attractiveness of the territory (Los, 2017; Kirillova, 2012). There are several directions for evaluating the landscape diversity of the territories. The most common evaluation method is a sociological survey focused mainly on identifying aesthetic preferences of various social groups (Lange and Hehl-Lange, 2011; Buchecker et al., 2003). However, due to the incompetence of the respondents, the results of the survey may be limited to identifying the preferences of various categories of tourists with reference to ways and places of recreation (Kuskov, 2008). The score-card and expert approaches are widespread in the assessment of the aesthetic qualities of the territory. The score-card system can be applied at various stages of the research. The main thing in the assessment is the definition of the system of indicators and the selection of scales for comparing them. The expert method is based on the scores.

The source of information here is the opinion of specialists (Kiprina, 2014; Frank et al., 2013; Kolesnikov, 2007). Both methods have a significant share of subjectivity, the reduction of which requires an increase in the volume of statistical data. Another way to reduce the subjective factor is the emphasis on quantitative descriptions of assessment indicators, based on modern digital technologies. The assessment methods of landscape diversity using geo-information systems (GIS), actively developing among researches, are becoming relevant (Bibayeva et al., 2018; Roth et al., 2013; Vargues et al., 2008; Štefunková et al., 2006; Fourie, 2005). As a result of a detailed analysis of existing methods, the choice fell on the method of M.A. Los (Los, 2017), the author used GIS technologies to assess the tourist potential of the relief, which significantly reduce the time and economic costs during the assessment, while maintaining high accuracy of the results.

\section{RESULTS DISCUSSIONS}

The territory of the ShchBRA is characterized by an abundance of hydrological resources in comparison with the surrounding areas. Let us consider the criteria of the favorableness of recreational properties of water bodies for beach-type tourism (Table 1).

The characteristics presented in Table 1, were estimated for the unique and largest lakes of the ShchBRA: Burabai, Shchuchye, Ulken Shabakty, Kishi Shabakty, Katarkol and Zhukei. Undoubtedly, the overall situation will change with the expansion of the list of criteria.

The absolute height of the relief of the considered lakes is within the frame of the interval corresponding to the most favorable degree for beach-type tourism (less than $500 \mathrm{~m}$ ). According to the maximum depth, Lakes Ulken Shabakty $(25,4 \mathrm{~m})$ and Shchuchye (23,1 $\mathrm{m})$ are 
classified as lakes of medium depth, Lake Kishi Shabakty - as rather shallow (10,38), the rest are shallow (Katarkol - 7,14 m, Burabai - 5,98 $\mathrm{m}$, Zhukei $-2,98 \mathrm{~m})$. Accordingly, all lakes are estimated at 5 points for this parameter, as well as for average depth and area. Climate comfort is an important aspect for the development of tourism. In the summer period, according to the tourist comfort index (Mieczkowski, 1985), all three months are assessed as comfortable for conducting excursions and active types of tourism (Yushina and Yegemberdiyeva, 2019). It is necessary to take into account the number of summer days with an average daily water temperature in the range of plus 18 to plus $22{ }^{\circ} \mathrm{C}$ for beach-type tourism (Table 2 ).

Table 1. The criteria for the properties of water bodies for beach-type tourism (Source: Comprises Rotanova et al., 2011 and Avakyan et al., 1987)

\begin{tabular}{|c|c|c|c|}
\hline \multirow{2}{*}{ Assessment indicators } & \multicolumn{3}{|c|}{ Degree of recreational favorableness } \\
\hline & Favorable (5 points) & Moderately favorable (3 points) & Unfavorable (1 point) \\
\hline Absolute height of the relief, $\mathrm{m}$ & $<500$ & $500 \ldots 1000$ & $>1000$ \\
\hline Maximum depth, m & $\begin{array}{l}\text { Of medium depth }(20 \ldots 49) \text {, rather } \\
\text { shallow }(10 \ldots 19) \text {, shallow }(<10)\end{array}$ & Deep (50..99) & $\begin{array}{c}\text { Very deep }(100 \ldots 200) \\
\text { exceptionally deep }(>200)\end{array}$ \\
\hline Medium depth, m & $\begin{array}{l}\text { Of medium depth }(7 \ldots 14) \text {, rather } \\
\text { shallow }(3 \ldots 6) \text {, shallow }(<3 \mathrm{~m})\end{array}$ & $\begin{array}{c}\text { Deep } \\
(15 \ldots 29) \\
\end{array}$ & $\begin{array}{c}\text { Very deep }(30 \ldots 60 \mathrm{~m}) \\
\text { exceptionally deep }(>60)\end{array}$ \\
\hline Water surface area, sq. km & $\begin{array}{c}\text { Large }(100 \ldots 500), \text { medium } \\
(20 \ldots 100), \text { small }(2 \ldots 20)\end{array}$ & $\begin{array}{c}\text { Small }(<2), \text { very large } \\
\quad(500 \ldots 5000)\end{array}$ & $\begin{array}{c}\text { Largest } \\
(>5000) \\
\end{array}$ \\
\hline Climate comfort (summer) & $\begin{array}{c}\text { Comfortable, } \\
\text { moderately comfortable }\end{array}$ & Low-comfortable & $\begin{array}{c}\text { Moderately uncomfortable, } \\
\text { uncomfortable }\end{array}$ \\
\hline $\begin{array}{l}\text { Number of summer days with an average } \\
\text { daily water temperature of } 18 \ldots+22^{\circ} \mathrm{C}\end{array}$ & $>60$ & $30 \ldots 60$ & $<30$ \\
\hline Transport accessibility, km & $\begin{array}{l}\text { Well accessible } \\
<100\end{array}$ & $\begin{array}{l}\text { Accessible } \\
100 \ldots 300\end{array}$ & $\begin{array}{l}\text { Poorly accessible } 301 \ldots 500, \\
\text { Practically inaccessible }>500\end{array}$ \\
\hline
\end{tabular}

Table 2. Number of summer days with an average daily water temperature of $+18 \ldots+22{ }^{\circ} \mathrm{C}$ (Source: The State Water Cadastre of the Republic of Kazakhstan, 2012-2014)

\begin{tabular}{|c|c|c|c|c|}
\hline \multirow{2}{*}{ Lake } & \multicolumn{3}{|c|}{ Year (number of days) } & \multirow{2}{*}{ Average } \\
\cline { 2 - 4 } & 2010 & 2011 & 2012 & \multirow{2}{*}{65} \\
\hline Ulken Shabakty & 82 & 61 & 51 & 78 \\
\hline Burabai & 92 & 81 & 61 & 58 \\
\hline Shchuchye & 82 & 51 & 41 & \\
\hline
\end{tabular}

According to Table 2, the duration of the period on Lake Burabai with a temperature comfortable for swimming is longer than on the other two lakes and is 78 days on average over 3 years. This criterion on Lake Shchuchye is estimated at 3 points, which naturally reduces the overall estimated favorableness. Although Lake Shchuchye in peak season is equal in popularity. This criterion is estimated at 5 points on lakes Burabai and Ulken Shabakty. When assessing the recreational resources of the lakes, it is necessary to pay attention to the structure and material of its shore, the availability of a beach and accessibility of water.

The nearshore zone of Lake Burabai has pinewood coverage of a medium density. A large open water table (10 sq.km.), overgrown with submerged plants except for maximum depth. Along the western and southern shores, there are small-area beds of reeds, rushes and water lilies (about $5 \%$ of the area). The bottom of the lake is flat and very silty in the southern part. The thickness of silt deposits in some places reaches $1-1,5 \mathrm{~m}$. The bottom is sandy in the northern and eastern parts of the lake. The eastern shore is more suitable for beach-type tourism, where tourism and recreational activities are intensively developing. The shores of Lake Shchuchye are predominantly gentle, and in the southwest they are moderately steep, merged with the slopes of hills covered with a pine forest. The shore line is broken with small nearshore bays. On the slopes, ancient near-shore natural levees are traced, which are formed by boulders and re-deposited crust of granite weathering. The water surface of the lake is open, without vegetation. The bottom at the northeastern and southwestern shores is sandy, at the southwestern - sandy and shingly, in some places silty, especially in the north (Saduokasova, 2015).

Lake Ulken Shabakty is located near the resort. To the south of the lake, there are slopes of the mountain range covered with mixed forest with a predominance of coniferous species, on the north side there is a hilly steppe plain covered with steppe mixed herbs, the eastern part of the basin is treeless. The shore line is crenellated with small bays and gulfs. In the western part in some places there are outcrops of massive rocks with steep slopes descending to the water. A peninsula shoots out into the lake from the west, beyond which a number of islands are located in the same direction, dividing the lake together with the peninsula into two unequal parts - the northern and southern, deeper one. In the northern part, in the area of the so-called "Sura shelf", another peninsula extends into the lake. The relief of the bottom of Lake Ulken Shabakty is complex with rather rapid increase in depth. The beaches in the western part are composed of coarse-grained sand and gravel, where there is an extensive shallow bay up to $1,5 \mathrm{~m}$ deep. The western, northern and eastern coasts to a depth of $1,5-2,0 \mathrm{~m}$ are free of silt deposits, because well washed. Pebble-gravel soils are located also around the ridge of islands, but they are strongly silt-covered. In the middle part of the lake, soils are composed of silts. Birch and birch-aspen forests surround the southern part of the shore near Lake Kishi Shabakty. On the southeastern shore of the lake, at a distance of $450-500 \mathrm{~m}$, a natural levee composed of inequigranular sand and large fragments of granite and crystalline schist can be traced. The southwestern part farther from the shore on the slopes of the mountains of Kokshetau is covered with pine forests. The lake water surface is open. The bottom near the shores is mainly sandy and sandy-and-shingly, closer to the middle - loamy, silty, and near the mountainous southeastern shore - stony. Hard vegetation is found to the depth of $3 \mathrm{~m}$.

The Katarkol lake water surface is open, small in area $(2-3 \%)$ stands of cane and reed are located mainly near the northwestern shore. The bottom near the shores is dense, sandy-loamy, in some places sandy-rocky, silty in the middle and in the western part. Along the shore and almost everywhere, the beach is composed of coarse-grained sand, pebble and shingle.

Of all lakes under consideration, Lake Burabai is the most popular among holiday-makers; there is an organized beach area, and also tourists actively float in catamarans and boats, make excursions and walks. In the northwestern part of the lake, in the Golu boy Bay, there is a small rocky island - Zhumbaktas, rising $20 \mathrm{~m}$ above the water, such natural objects are of outstanding interest among tourists.

Transport accessibility of the lakes is good. A dense transport network passes through the resort area, and there is a developed network of recreation centers, resorts, camp sites and health centers. Many tourist routes and trails are developed for ecological and active types of tourism. It is possible to rent bicycles on the territory, which makes it possible to organize a cycle tour along the lakes. Some water bodies can only be used for recreational and sport fishing. In our case, in the context of tourism development, it should be taken into account that the 
ShchBRA is located within the specially protected nature area, where tourist and recreational activities are carried out subject to the need to conserve and restore ecosystems and given environmental restrictions. In $20-60 \%$ of the territories of the lakes of Burabai, Ulken and Kishi Shabakty, a conservation or regulated water use regime is partially established, which ensures the protection of these sites. On Lakes Shchuchye and Katarkol, the conservation regime of protection covers up to $90 \%$ of the total area.

Estimation of the tourism potential of the flora of the ShchBRA territory is done on the basis of scoring according to the species diversity of plant communities, a 4-point scale was developed (Figure 2). The following were considered in order to assess the territory: natural zonal characteristics of territories, forest areas and species diversity of vegetation. The most favorable ecosystems are the forest ones, where the forests themselves are an important resource of landscape-aesthetic perception and healing of holidaymakers through the ionization and phytoncidal properties of plants. There is a latitudinal zonality traced in the spread of vegetation cover, which is partially disturbed by the relief. The vegetation of the ShchBRA is represented by five main types: forest, forest-steppe, steppe, meadow and solonchak. A significant area of forest tracts is occupied by pine and pine-birch forests. The elevated plains between forest tracts are occupied by steppes and forest steppes. Meadow communities are local and rather small in area. Different salinity of soils and soil-forming material, insufficient drainage of the territory leads to complexity, to a combination of areas of zonal vegetation with halophytic vegetation of solonetzes.

According to I.V. Kopyl, seven main plant communities are distinguished in the territory of the ShchBRA (Figure 2):

1 - In the central part of the ShchBRA, pine, pine-birch forests with dead soil covering, forests with lichen and grass layers (Pinus silvestris, Betula verrucosa, Cladonia Alpestris, Ramischia secunda) are concentrated on weakly-developed sod-podzolic and grey forest soils in the areas of the development of granitoids, where there is the presence of rare and Red Book species of vegetation - territories with a favorable degree of tourist potential for the development of scientific and ecological types of tourism;

2 - Forbs-grass meadow steppes (Stipa rubens, Festuca sulcate, Phleum phleoides, Medicago falcate, Pulsatilla tlavescens) in combination with pine-birch and birch steppificated forests (Betula verrucosa, Pinus silvestris, Calamagrostis arundinacea, Festuca sulcata, Ramischia secunda) in the south and east of the assessed territory also have a favorable degree of tourist potential and contribute to the development of various types of tourism, associated mainly with ecological tourism;

3 - Also, the southern and eastern areas of the territory are influenced by the rich in herbs red-feather grass steppe (Stipa rubens, Festuca sulcata, Phleum phleoides, Filipendula hexapetala, Lathyrus tuberosus, Onobrychis sibirica) in combination with birch, aspen-birch forests and forest outliers (Betula verrucosa, Populus tremula, Calamagrostis epigeios, Rubus saxatilis, Trifolium lupinaster) the territories with a moderate degree of tourism potential, more suitable for the development of commercial types (berries and mushrooms collecting) of tourism;

4 - Forbs-red feather grass steppes (Stipa rubens, Festuca sulcate, Salvia stepposa, Phlomis tuberosa, Seseli ledebourii) - occupy a small territory in the east and have characteristics similar to the rich in herbs red-feather grass steppe in the north-west;

5 - In the west of the ShchBRA - petrophytous forbs-oak grass-feather grass steppes (Stipa rubens, Stipa capillata, Helictotricnon desertorum, Festuca suicata, Scabiosa isetensis, Artemisia frigida, Artemisia marschalliana, Orostachys spinose, Seseli ledebourii) - the territory, relatively favorable for the development of scientific, commercial and ecological types of tourism;

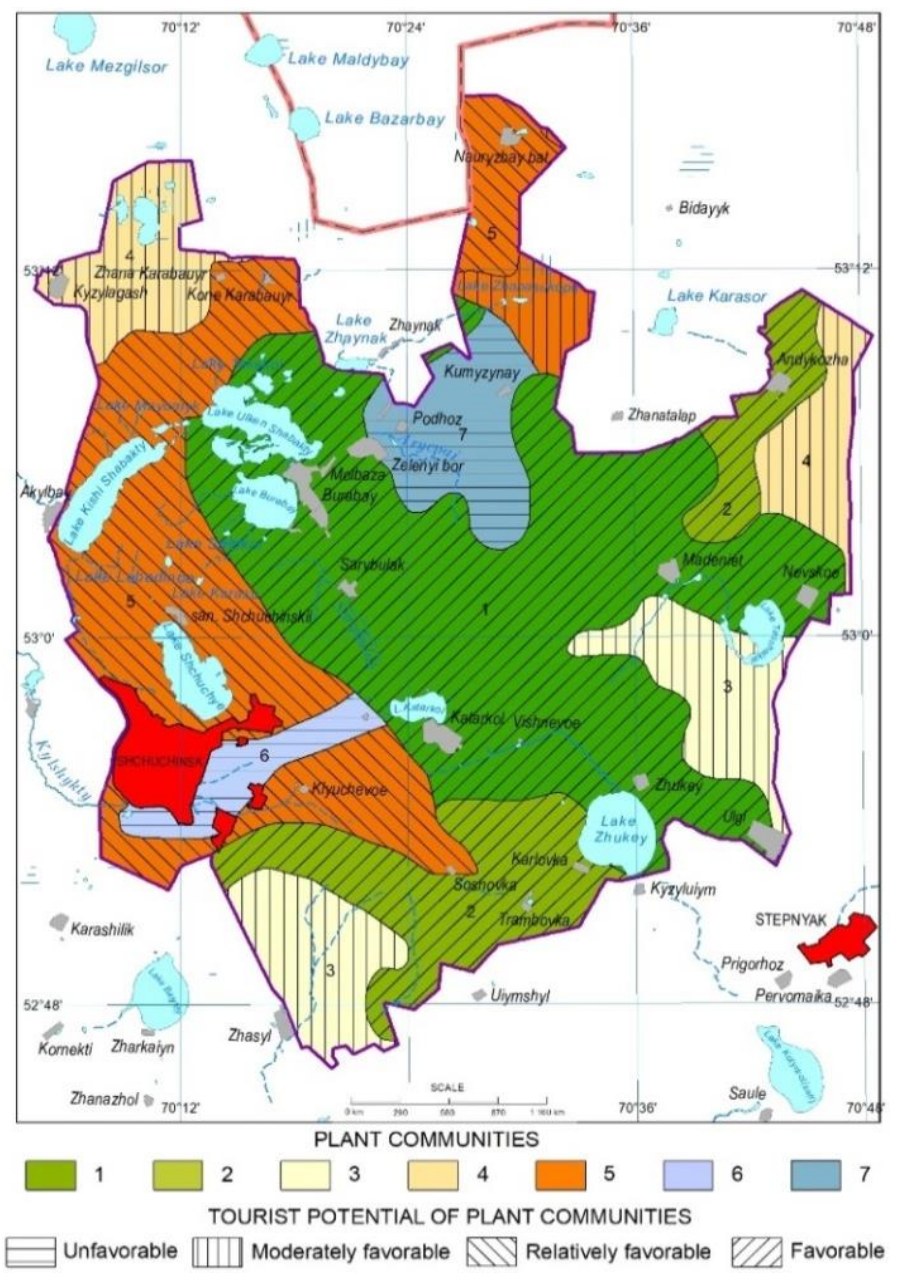

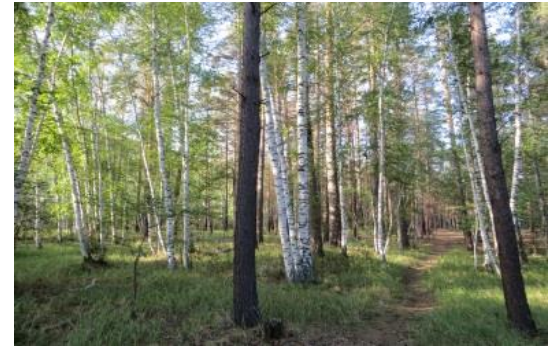

Territories with a favorable degree of tourist potential, based on the plant assessment

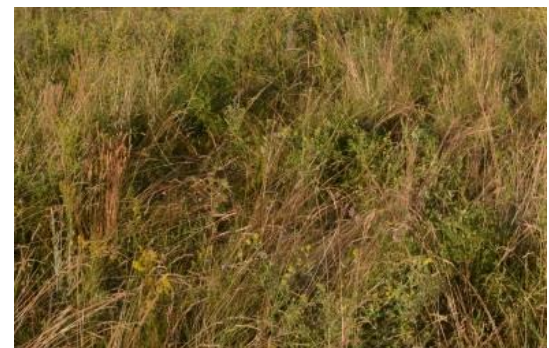

Territories with a relatively favorable degree of tourist potential, based on the plant assessment

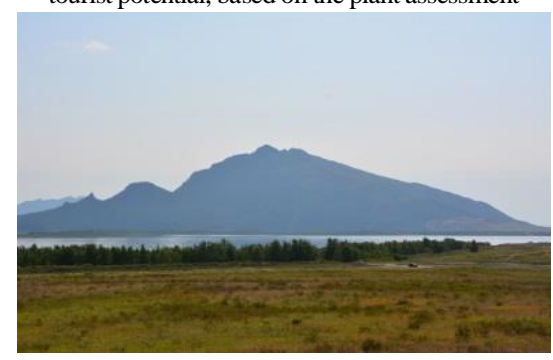

Territories with an unfavorable degree of tourist potential, based on the plant assessment

Figure 2. Map of tourist potential of plant resources of the ShchBRA (Source: Atlas of Northern Kazakhstan, 1970) 
6 - Wheatgrass, bromegrass, sedge and reed grass meadows with forbs (Agropyrum repens, Bromus inermis, Aneurolepidium ramosum, Calamagrostis epigeios, Puccinellia tenuissima, Lymomum gmelinn, Sanguisorba ofticinalis), in some places halophytic - with the participation of Artemisia nitrosa and annual halophytic groupings occupy the northern part of ShchBRA and have an unfavorable degree for the development of tourism;

7 - Goldilocks-sheep's fescue, wormwood-sheep's fescue halophytic groupings (Festuca sulcate, Linosyris villosa, Artemisia nitrosa, Artemisia latifolia, Galatella subglabra) in combination with zonal vegetation stretch in a strip east of the city of Shchuchinsk and have an unfavorable degree for the development of tourism.

One of the most important factors that are taken into account in the assessment of the tourist potential of the territory is geomorphological resources. The relief acts as a frame that affects the psychological-aesthetic state of a person and forms the internal landscape diversity of the territory. It is the relief that largely determines the morphological structure of the landscape, creates a variety of facies and natural boundaries that form the landscape structure (Kirillova, 2012). The initial data in the assessment of the tourism and recreational potential of the relief of the ShchBRA are a digital elevation model (DEM) with a resolution of $30 \mathrm{~m}$, topographic and geomorphological maps of the territory of the ShchBRA at a scale of 1:200 000. The calculations were made using the tools of the standard Spatial Analyst ArcGIS module. The first stage of the tourist assessment of the relief of the ShchBRA was dividing of its territory into squares with the size of $300 \times 300 \mathrm{~m}$. Further, the values of morphometric characteristics of the relief were calculated within these squares and each square obtained its own score (1-5) for each indicator (Los, 2017) (Table 3).

Table 3. Assessment of the relief according to morphometric characteristics (Source: Modified by Yegemberdiyeva from Los, 2017)

\begin{tabular}{|c|c|c|c|c|c|c|c|}
\hline \multicolumn{2}{|c|}{ Vertical ruggedness } & \multicolumn{2}{|c|}{ Horizontal ruggedness } & \multicolumn{2}{|c|}{ Surface slope } & \multicolumn{2}{|c|}{ Slope aspect } \\
\hline $\mathrm{m}$ & points & $\mathrm{m} / \mathrm{m}^{2}$ & points & degrees & points & aspect & points \\
\hline $0-25$ & 1 & 0 & 1 & $0-4$ & 1 & flat surface & 1 \\
\hline $25-55$ & 2 & $0-0,010$ & 2 & $4-7$ & 2 & $\mathrm{~N}$ & 2 \\
\hline $55-85$ & 3 & $0,010-0,016$ & 3 & $7-15$ & 3 & NE, NW & 3 \\
\hline $85-115$ & 4 & $0,016-0,022$ & 4 & $15-25$ & 4 & E, W & 4 \\
\hline $115-255$ & 5 & $0,022-0,030$ & 5 & $25-55$ & 5 & SE, S, SW & 5 \\
\hline
\end{tabular}

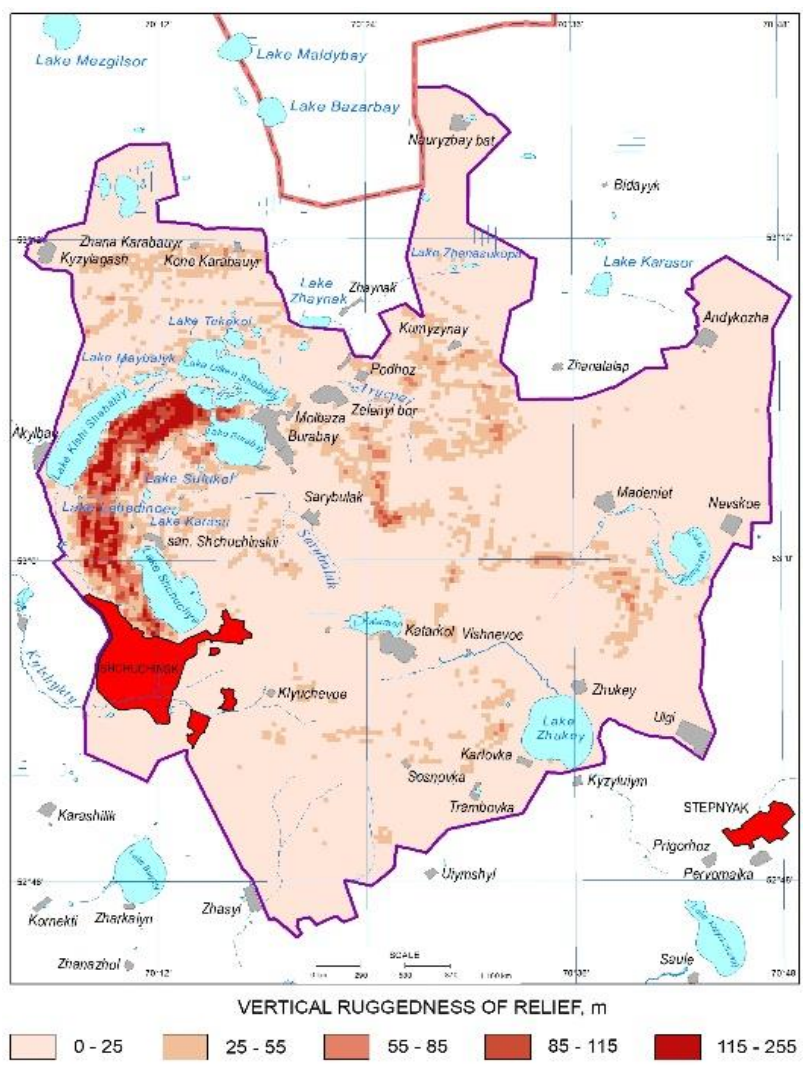

Figure 3. Map of vertical ruggedness of the relief of the ShchBRA (Source: Based on SRTM, 2000)

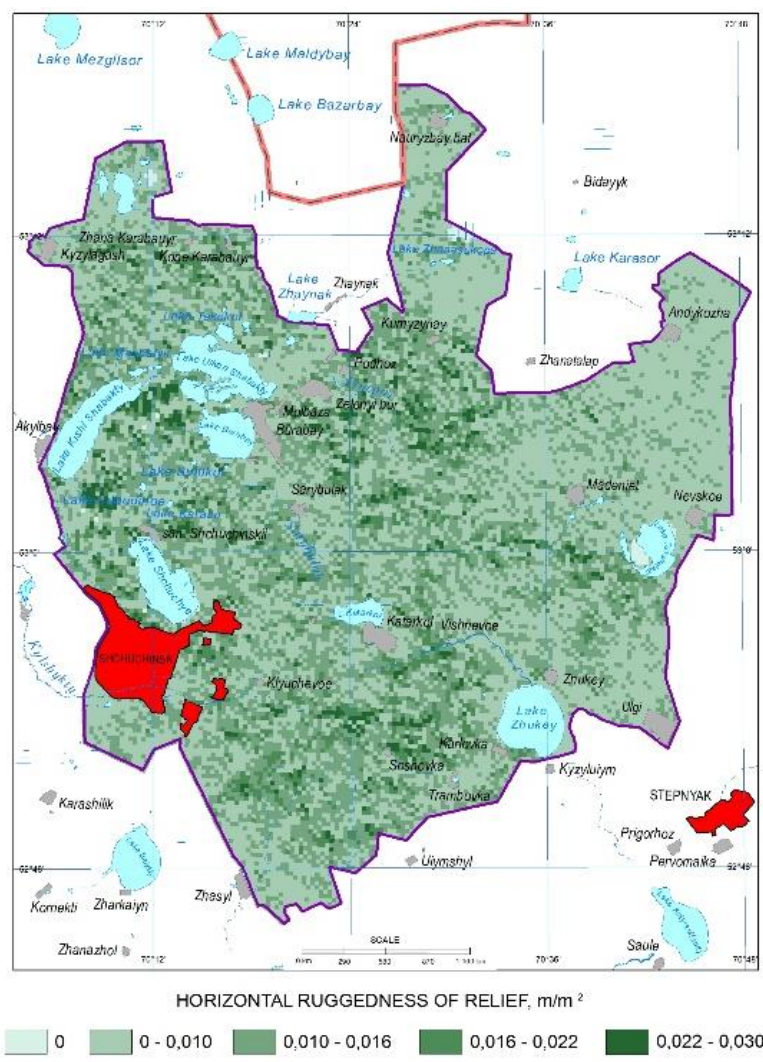

Figure 4. Map of horizontal ruggedness of the relief of the ShchBRA (Source: Based on SRTM, 2000)

The vertical ruggedness of the relief of the ShchBRA was determined with the use of the Zonal Statistics tool, where, within the selected squares, the difference between the smallest and largest values of all cells of the raster that belong to the same zone as the output cell (RANGE) (Figure 3). The vertical ruggedness of $95 \%$ of the entire territory of the ShchBRA got the lowest score. The ridge-shaped undulating low mountains of the Kokshetau Upland - the mountains Kokshe, Bura, Zheke Batyr, as well as Lysaya Mountain obtained the highest value and the highest score. The density of the ruggedness of the relief (development of the erosion network) was calculated using the tools of the Hydrology group: Fill, Flow Direction, Flow Accumulation, Stream Link, Stream Order and Stream to Feature.

Then, using the Dissolve, Intersect and Join Features tools, the length of the erosion network within the selected squares was calculated (Figure 4). According to the results of the assessment, the horizontal ruggedness of more than $80 \%$ of the territory of the ShchBRA equals to $2(52,2 \%)$ and $3(31,5 \%)$ points. The surface slope was calculated with the use of the Slope tool of the Surface group of tools (Figure 5). For each cell, the slope tool calculates the maximum degree of change in the $z$ value between a particular cell and its neighboring cells 
(http://desktop.arcgis.com). It is commonly supposed that the steepness of the slopes most attractive for tourism development starts from 30$40^{\circ}$ (Garms et al., 2013). The highest values of the slope $\left(25-55^{\circ}\right)$ are characteristic of the ridge-shaped undulating low mountains and the denudation hillocky area of the Kazakh Upland. The aspect was determined using the Aspect tool of the Surface group of instruments (Figure 6). This tool extracts the aspect of slopes from a raster surface. The aspect determines the direction of the slope of the maximum rate of change of values from each cell to its neighboring cells (http://desktop.arcgis.com).

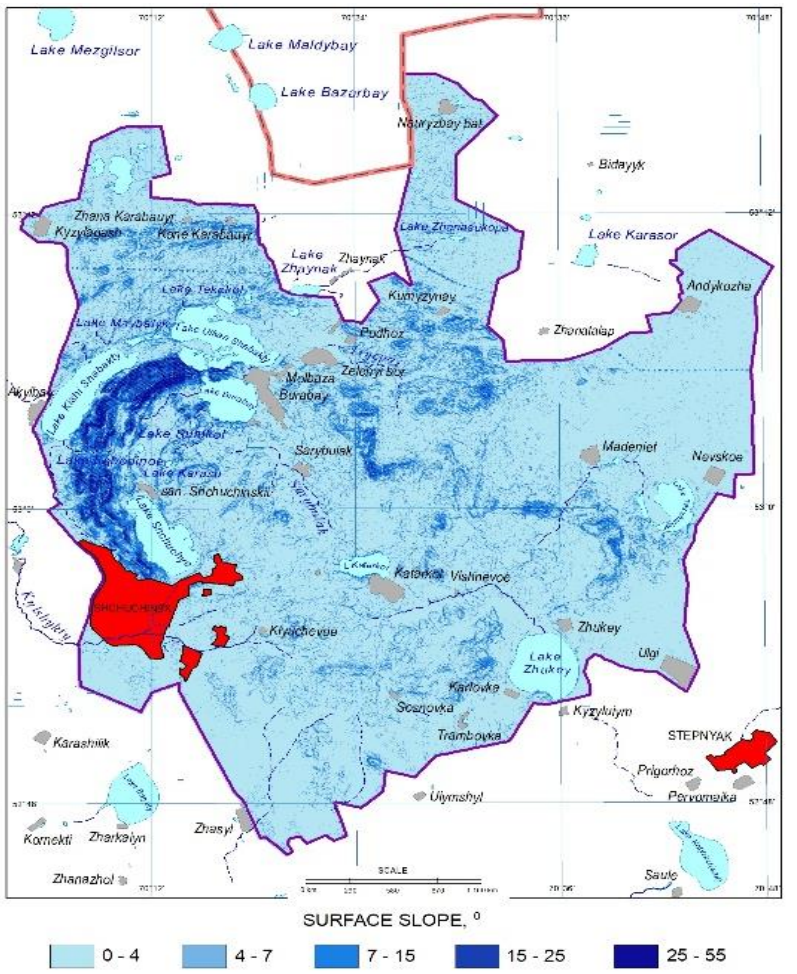

Figure 5. Map of the slope of the surface of the ShchBRA (Source: Based on SRTM, 2000)

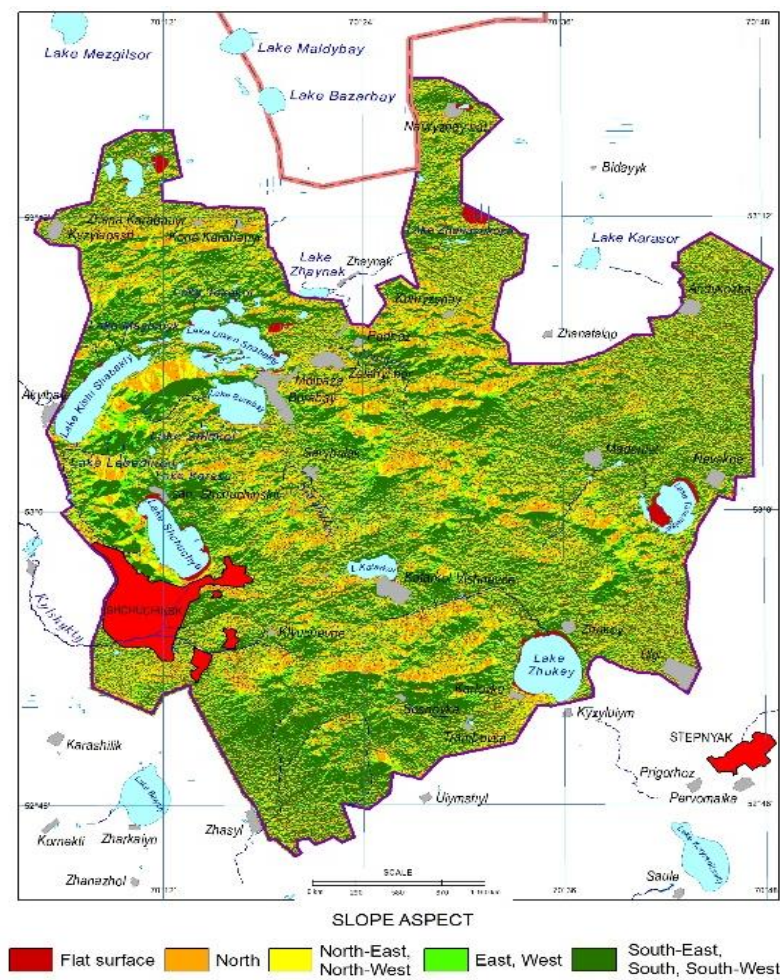

Figure 6. Map of the slopes aspects of the ShchBRA (Source: Based on SRTM, 2000)

On the map of the slopes aspects of the ShchBRA, the lowest score was obtained by the flat surface, the highest - the southeastern, southern and southwest expositions of the slopes of the ShchBRA. Further, using the Map Algebra tool, the average value of the sum of 4 morphometric characteristics of the relief of ShchBRA, ranked on a five-point scale, was calculated (Figure 7). However, in order to assess the landscape diversity, it is necessary to consider also the vegetation of the territory, since the landscape is enriched and additional opportunities for tourism are created in combination with this component. According to the results of various assessments, mixed mature woodland with crown density, sparse or poorly expressed underwood is considered the most attractive (Kuskov, 2008). The data on the woodlands of the ShchBRA were obtained from topographic maps at a scale of 1: 200000 , for equivalence with other morphometric indicators, the layers of the woodlands were converted to raster format, if there is a woodland -1 point is assigned, if no -0 is assigned (Figure 8 ).

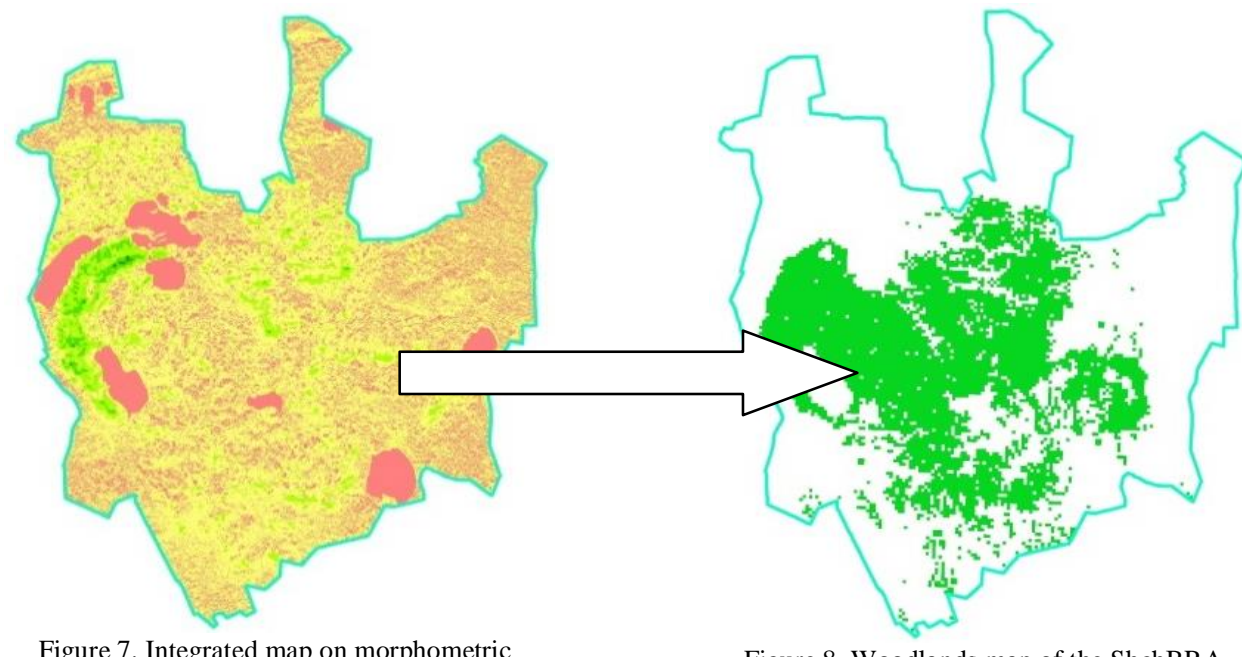

Figure 8. Woodlands map of the ShchBRA

(Source: Developed by Yegemberdiyeva)

(Source: Topographic maps, scale 1:200 000)

Summing up the points of the integrated map according to morphometric characteristics and woodlands map made it possible to obtain a map of the landscape diversity of the ShchBRA territory (Figure 9) by 5 degrees: unfavorable, scarcely favorable, moderately favorable, 
relatively favorable and favorable. The mountains Kokshe, Zheke Batyr and the high elevations of Shchuchinskaya Sopka, where the vertical ruggedness varies from 115 to $255 \mathrm{~m}$, horizontal ruggedness - from 0,022 to $0,030 \mathrm{~m} / \mathrm{m}^{2}$, the surface slope is from 25 to 55 degrees with southeast, southern and southwest aspect of the slopes, are the territories with a favorable degree of landscape diversity. Territories with absolute elevation from 400 to $900 \mathrm{~m}$ such as Kokshetau Upland, the mountains of Mailykora, Sarykaska, Lysaya, Burkitti, Semyonov Sopka and others, have a relatively favorable degree. The rest of the territory of the ShchBRA is flat, but because of the assignment of 1 point due to the presence of the woodland, territories with a moderately favorable degree were identified. Territory with scarcely favorable and unfavorable degree of landscape diversity occupies about $60 \%$ of the total area of the ShchBRA. Here, the vertical ruggedness varies from 0 to $55 \mathrm{~m}$, the horizontal ruggedness - from 0 to $0,010 \mathrm{~m} / \mathrm{m}^{2}$, the surface slope does not exceed $5^{\circ}$.
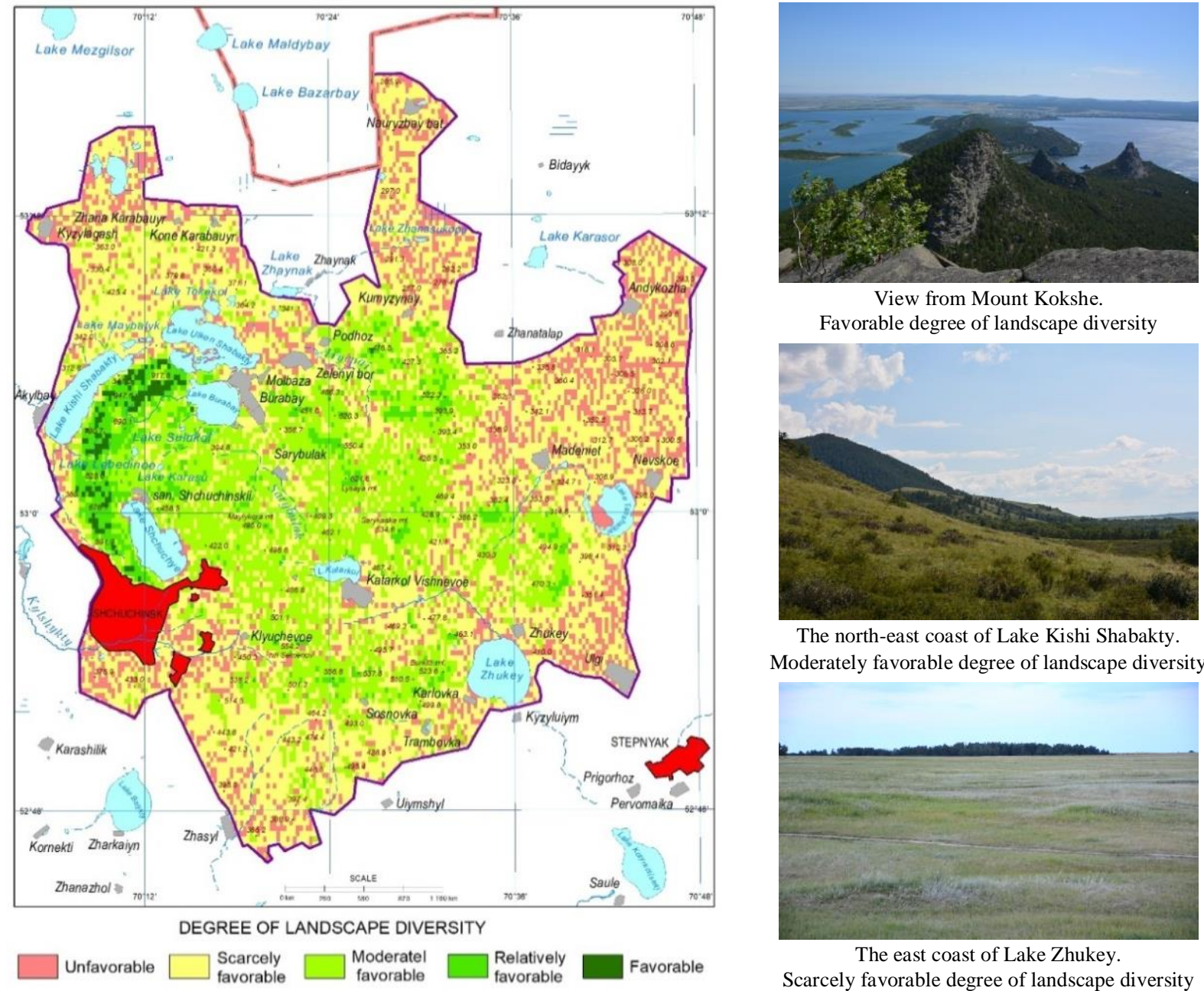

View from Mount Kokshe.

Favorable degree of landscape diversity

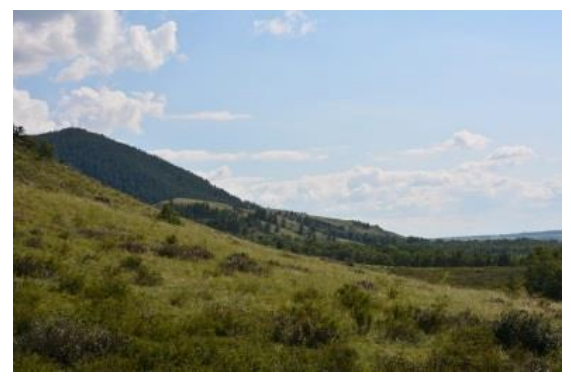

The north-east coast of Lake Kishi Shabakty. Moderately favorable degree of landscape diversity

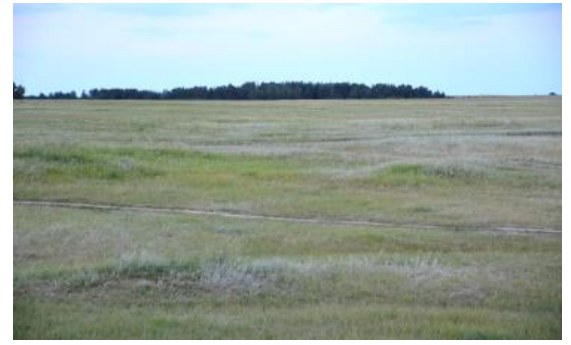

The east coast of Lake Zhukey.

Scarcely favorable degree of landscape diversity

Figure 9. Map of landscape diversity of the ShchBRA (Source: Developed by Yegemberdiyeva, 2019)

\section{CONCLUSION}

As a result of the conducted research, it was revealed that on the lakes Burabai, Shchuchye, Kishi and Ulken Shabakty there is a decrease in the transparency of water and siltation of the bottom, as well as an intensive anthropogenic change in the landscape in the form of trampling down of the soils, the development of erosion processes, baring of the root system of pine plantations is observed. There are multiple mechanical damages to the vegetation cover. The lowest recreational load on the lakes Katarkol and Zhukei is explained by the remoteness of the water bodies from settlements and less developed tourist infrastructure.

Undoubtedly, Burabai, Shchuchye, Kishi and Ulken Shabakty lakes take on the largest flow of tourists, as they are the hallmark of the ShchBRA. In the eastern part of all lakes, where the shore is most suitable for beach-type tourism, there are settlements with a developed network of hotels, rest houses, sanatoriums and camp sites. Lakes are a key link for many routes. All this, in total, have a negative impact on the ecological state of valuable water bodies for the development of tourism and indicates the need for sustainable management of natural resources and the distribution of tourist flows. Territories with pine and pine-birch forests in the central part of the ShchBRA, as well as forbgrass meadow steppes with pine-birch and birch steppificated forests in the south and east are favorable for the development of scientific and ecological types of tourism. Petrophytous forbs-oat grass-feather grass steppes with relatively favorable degree are common for the development of scientific, commercial and ecological types of tourism. Southern and eastern areas of the ShchBRA with a moderate degree of tourist potential are occupied by rich in herbs red-feather grass steppe in combination with birch, aspen-birch forests and forest outliers, and also forbs-red feather steppes are more suitable for the development of commercial types (berries and mushrooms collecting) of tourism. Steppe and meadow areas in the north and west of the ShchBRA, goldilocks-sheep's fescue, wormwood-sheep's fescue halophytic groupings have an unfavorable degree for the development of tourism. Mostly, the botanical resources of the ShchBRA perform a resource function. Currently, berry, mushroom grounds and grounds with medicinal herbs are actively used for the development of hiking and commercial tourism near settlements or medical-recreational objects of the ShchBRA. The ionization and phytoncidal properties of the pine and pinebirch forests of the ShchBRA are also used, because they contribute to the increase in oxygen content in the air and its ionization - the 
process of formation of ions in the air, which has a cleansing effect on the human body. The mountains Kokshe, Zheke Batyr and the high elevations of Shchuchinskaya Sopka are the territories with a favorable degree of landscape diversity. These territories are favorable for the development of sports types of tourism, such as hiking and mountaineering, as well as alpine climbing, speleo-tourism, mountain skiing. Hiking can be developed almost throughout the entire territory of the ShchBRA, but due to the height of the terrain and steepness of the slopes, the route in this section can be difficult and require physical training of tourists. The relief of this area is low-mountain, and accordingly here it is necessary to develop low-mountain hiking routes in places, where the climbs are convenient enough.

The Kokshetau Upland, the mountains Mailykora, Sarykaska, Lysaya, Burkitti, Semyonov Sopka and others - these are territories with a relatively favorable degree of landscape diversity, advantageous for the development of medical-recreational and sports tourism. Ridgeshaped and hilly relief of the Kokshetau Upland is most favorable for recreational purposes, as well as for the placement of medicalrecreational facilities. At the same time, there is great potential for the development of sports tourism in these territories, as example of this is the Republican Ski Resort in Shchuchinsk. The rest of the territory of the ShchBRA is flat, on which a moderately favorable degree of landscape diversity was identified due to the presence of the woodland. These territories have the potential for the development of hiking and wellness tourism, including berries and mushrooms collection. The territory with a scarcely favorable and unfavorable degree of landscape diversity occupies about $60 \%$ of the total area of the ShchBRA. The relief of this territory is aesthetically not very expres sive and unfavorable for tourism. Summarizing the above, it can be noted that the ShchBRA has the potential for the development of ecological tourism, which implies active types of tourism and recreational activities. But at the same time it should bear in mind that ShchBRA is located within the specially protected natural area, i.e. tourism and recreational activities should be carried out taking into account ecological capacity, the need to conserve and restore ecosystems, as well as environmental restrictions set.

\section{Aknowlegments}

The article uses the research results obtained in the framework of Projects № AP05131504 "Scientific and applied foundations of tourism resource management based on Web-technologies using the example of Northern Kazakhstan” and № BR05236529 "Integrated assessment of the ecosystems of the Shchuchinsk-Borovoye Resort Area with the determination of environmental load for sustainable management of recreational capacity".

\section{REFERENCES}

Akhmatov, S.V. (2012). Geo-ecological assessment of the recreational potential of the lakes of the Chuya river basin. Abstract of the thesis of the Cand. of Geogr. Sci. "25.00.36 - Geoecology”, Tomsk, p. 22.

Avakyan, A.B., Saltankin, V.P., \& Sharapov, V.A. (1987). Reservoirs, Moscow, p. 23.

Bibayeva, A.Y., \& Makarov, A.A. (2018). The use of GIS for calculating complex indicators of aesthetic assessment of landscapes. News of Irkutsk State University. Earth Sciences Series, 24, 17-33.

Buchecker, M., Hunziker, M., \& Kienast, F. (2003). Participatory landscape development: Overcoming social barriers to public involvement. Landscape and Urban Planning, 64(1-2), 29-46.

Buzyakova, I.V. (2006). Geo-ecological assessment of the Volga delta, the Volga-Akhtuba floodplain and the western Ilmen-Bugrovyi landscapes of the Astrakhan region for the development of various types of water tourism. Abstract of the thesis of the Cand. of Geogr. Sci. "25.00.36 - Geoecology", Kaluga, p. 23.

Dancheva, A.V., Mukanov, B.M., \& Zalesov, S.V. (2013). Clarification of the functional zoning of pine plantations of the SNNP "Burabai" by the value of recreational loads. Research, results, no. 3, p. 109.

Dorofeyev, A.A. (2003). Landscape-recreational analysis of the territory for the purpose of ecological tourism: based on the example of the Tver region. Abstract of the thesis of the Cand. of Geogr. Sci. "25.00.23 - Physical geography and biogeography, soil geography and geochemistry of landscapes", Smolensk, p. 23.

Fourie, R. (2005). Applying GIS in the evaluation of landscape aesthetics. Thesis. Master of arts, Geography and Environmental Studies, Stellenbosch, 70 p.

Frank, S., Fürst, C., Koschke, L., Witt, A., \& Makeschin, F. (2013). Assessment of landscape aesthetics-Validation of a landscape metrics-based assessment by visual estimation of the scenic beauty. Ecological indicators, 32, 222-231.

Garms, Y.O., Khromykh, V.V., \& Sukhova, M.G. (2013). The use of GIS in the assessment of geomorphological resources for the purpose of recreation (based on the example of the transboundary Gorny Altai). Modern problems of science and education, Internet journal, no. 6.

Gordeziani, T.P., Beruchashvili, N.N., Gorgodze, T., Jincharadze, G.A., Mamukashvili, T.U., Sharashenidze, M.D. (2011). Compilation of an expert geoinformation system and electronic atlas of a promising tourism and recreational complex of the Shaori reservoir and its surroundings. InterCarto, InterGIS 17: Sustainable development of territories: GIS theory and practical experience, Barnaul, p. 408-416.

Hakim, L., \& Soemarno, M. (2017). Biodiversity conservation, community development and geotourism development in Bromo-Tengger-Semeru-Arjuno Biosphere Reserve, East Java. GeoJournal Tourism and Geosites, 20(2), 220-230.

Khromeshkin, V.M., \& Shagdurov, A.A. (2015). The concept and result of mapping of recreation on the Baikal coast. Atlas mapping: traditions and innovations: Proceedings of the Xth scientific conference on thematic mapping, Irkutsk, 54-56.

Kirillova, A.V. (2012). Relief as a factor in the aesthetic attractiveness of the landscape. Bulletin of Udmurt University, Biology Series, Earth Sciences, 2, 104-108.

Kiprina, Y.N. (2014). Tourism resource studies: a training manual. Tyumen State University Publishing House, Tyumen, p. $72-79$.

Kolesnikov, D.A. (2007). A review of existing methods for assessing recreational areas. GeoSiberia 2007-International Exhibition and Scientific Congress, 6 , 206-209.

Kolotova, Y.V. (1999). Recreational resource management: A manual for students enrolled in the specialty of "Management", Moscow, p. 113.

Kuskov, A.S., Golubeva, V.L., \& Odintsova, T.N. (2005). Recreational geography. Educational-methodical complex, Flint Moscow Psychological and Social Institute, Moscow, p. 496.

Kuskov, A.S. (2008). Tourism resource management: Textbook for students of higher institutions, Academy Publishing Center, Moscow, p. 113-114.

Lange, E., \& Hehl-Lange, S. (2011). Citizen participation in the conservation and use of rural landscapes in Britain: the Alport Valley case study. Landscape and Ecological Engineering, 7(2), p. 223-230. https://doi.org/10.1007/s11355-010-0115-2.

Lazitskaya, N.F. (2014). Socio-geographical justification for the development of recreational water use in Sevastopol. Abstract of the thesis of the Cand. of Geogr. Sci. "25.00.24 - Economic, social, political and recreational geography”, Simferopol, p. 326

Litvinov, A.Y. (2013). Assessment of the recreational potential of water bodies in the mountain-foothill part of the Northwest Caucasus. Abstract of the thesis of the Cand. of Geogr. Sci. "25.00.24 - Economic, social, political and recreational geography”, Krasnodar, p. 21.

Los, M.A. (2017). Assessment of the relief of the Tyumen-Tobolsk tourist and recreational framework in order to develop tourism. Geographical bulletin. Tourism and recreational geography, 4(43), 161-169.

Mieczkowski, Z. (1985). The tourism climatic index: a method of evaluating world climates for tourism. The Canadian Geographer, no 3, vol. 29 , p 220-233.

Mirsanjari, M.M., Angali, K.A., Dhumal, K.N., \& Gavali, R.S. (2007). Importance of lakes potential for development of ecotourism in Pune district. In Proceedings of Taal 2007: The 12th World Lake Conference, 1186-1196. 
Mukayev, Zh.T. (2015). Geo-ecological assessment of the territorial and recreational systems of Lake Alakol basin. Thesis (PhD) «6D060900 - Geography», Almaty, p. 171.

Mutaqien, Z., \& Zuhri, M. (2011). Establishing a long-term permanent plot in remnant forest of Cibodas Botanic Garden, West Java. Biodiversitas Journal of Biological Diversity, 12(4).

Orlova, M.S. (2010). Sea coast of Crimea as a resource of recreation (based on the example of the coast of Western Crimea). Abstract of the thesis of the Cand. of Geogr. Sci. “25.00.25 - Geomorphology and evolutionary geography”, Moscow, p. 26.

Radojević, I., Stefanović, D., Čomić, L., \& Nikolić, N. (2007). Database - Serbian Lakes and Reservoirs - SeLaR. Kragujevac Journal of Science, $29,85-90$.

Rotanova, I.N., \& Nikolayev, O.P. (2011). GIS in ensuring ecological and recreational safety of the population. Interexpo Geo-Siberia, 21(2), 137-142.

Roth, M., \& Gruehn, D. (2012). Visual landscape assessment for large areas - using GIS, internet surveys and statistical methodologies in participatory landscape planning or the federal state of mecklenburg-western Pomerania, Germany. Proceedings of the Latvian Academy of Sciences, Section A : Human and Social Sciences, 129-142.

Saduokasova, M.T. (2015). Study of changes in the water balance of the Shchuchinsk-Borovoye Resort Area in the conditions of modern climate and water consumption, Report, Almaty, Al-Farabi KazNU, p. 20-21.

Staroverkina, N.N. (2007). Comprehensive assessment of the tourism and recreational potential of the Republic of Kalmykiya. Abstract of the thesis of the Cand. of Geogr. Sci. "25.00.23 - Physical geography and biogeography, soil geography and landscape geochemistry”, Volgograd, p. 23.

Shevtsova, N.S. (2001). Comprehensive assessment of the recreational natural potential of the water areas of lakes in Belarus. Abstract of the thesis of the Cand. of Geogr. Sci. “25.00.36-Geoecology”, Minsk, p. 20.

Štefunková, D., \& Cebecauer, T. (2006). Visibility analysis as a part of landscape visual quality assessment. Ekológia, Bratislava, Supplement, 25(1), 229-239.

Sultangazina, G.Zh. (2015). To the current assessment of the flora of the Burabai National Park: floristic aspect. News-bulletin of the NAS RK, Biol. and Med. Series, Almaty, no.3 (309), 64-70.

Vargues, P., \& Loures, L. (2008). Using Geographic Information Systems in Visual and Aesthetic Analysis: the case study of a golf course in Algarve. Wseas transactions on environment and development, 4(9), 774-783.

Yegemberdiyeva, K.B., Temirbayeva, R.K., Orazbekova, K.S., \& Khen, A.P. (2018). Determination of monitoring sites for assessing the recreational load on the ecosystem of the Shchuchinsk-Borovoye Resort Area. Problems of Geography and Geoecology, Almaty, 3,19-26.

Yushina, Y., \& Yegemberdiyeva, K. (2019). Assessment of tourism and recreational potential of climatic resources of the Akmola region (Kazakhstan). XIX International Multidisciplinary Scientific GeoConference SGEM (28 June - 7 July), 69-75.

Ziganshin, I.I., \& Ivanov, D.V. (2016). Tourism and recreational potential of specially protected water bodies of the Republic of Tatarstan. Russian Journal of Applied Ecology, 4(8), 47-54.

*** (1970). Atlas of Northern Kazakhstan, Moscow.

*** (2018). Nature records 2017. Property and Facilities Management Office under the President of the Republic of Kazakhstan, Burabai State National Nature Park, p. 140

*** $(2012,2013,2014)$. The State Water Cadastre of the Republic of Kazakhstan. Annual data on the dynamic and resources of surface land waters, 20102012, Part 2. Lakes and reservoirs. Issue 2. Esil River Basin.

http://desktop.arcgis.com/ru/arcmap/10.4/tools/spatial-analyst-toolbox/, accessed 10.06.19. 